\title{
Strength Of Proof Of Examination Result Of Financial Auditing Body In Case Of Corruption Crime HambaliThalib $^{1}$, MuinFahmal ${ }^{1}$, BaharuddinBadaru ${ }^{1}$, KaharuddinSyah ${ }^{1,2}$ \\ ${ }^{1}$ Faculty of Law, Universitas Muslim Indonesia \\ ${ }^{1 ' 2}$ Doctoral Students of Legal studies, Universitas Muslim Indonesia and Faculty of Law, Universitas muhammadiyah Palu, Indonesia \\ Corresponding Author:HambaliThalib
}

\begin{abstract}
Articulation of a word of power of proof can be interpreted as something that is multak, legitimate and perfect in a criminal case, especially corruption criminal case. The absoluteness, validity, and perfection of the evidence are directed to a proof of CPC audit or more familiar with CPC audit results. Proof means sufficient evidence to show the truth of an event, so that proof means a deed to prove something truth, execute, signify, witness and convince.The evidence of the inspection result is the source of the rule of law number 15 of 2006 concerning the Supreme Audit Agency (CPC), which in the period of 8 paragraphs 3 and 4 states: If in the investigation is found criminal element, CPC reports it to the authorized institution in accordance with the provisions of the law - invitation no later than 1 (one) month since the existence of such criminal element is known. And the CPC Report as referred to in paragraph (3) shall be the basis of investigation by the competent investigating authority in accordance with the laws and regulations. From this comes the matter of the strength of the proof of the CPC report referred to in the article and the accountability that can be tested in a court process. This research uses normative juridical research method by tracing secondary and primary materials that are closely related to the object of research. The secondary materials in question are the invitees, scientific writings, scientific articles and others.
\end{abstract}

Keywords: Proof, Strength, Audit Result.

Date of Submission: 12-03-2018

Date of acceptance: $29-03-2018$

\section{INTRODUCTION}

Proof is the provisions that contain the rulings and guidelines on the law-justified ways, proving the defendant's accusations to the defendant. Evidence is a provision that regulates the evidence substantiated by law, used by a judge in proving wrongs indicted in the trial, and is not justified in proving thedefendant's wrongdoing with nojuridical and justice grounds.

Discussing the strength of proof of a result of the examination of the financial auditing body is quite interesting because the struggle of financial audit result from CPC can have implication on the action against law which can harm the state finance which lead to corruption crime. In understanding the strength of the proof of CPC audit results in cases of non-criminal corruption thinking analysis we have to touch aspects of state administrative law and criminal law aspects. The law of state administration is closely related to the state organizer as the subject having a role in the management of state finances. From the aspect of punishment determine in relation to the state losses stated in article 2 and 3 of Law Number. 31 year 1999 jo. Act number. 20 of 2001 on the eradication of non-criminal corruption.

In the provisions of laws and regulations, stated that :

If the investigation is found to be a criminal element, the CPC shall report the matter to the competent authority in accordance with the provisions of legislation no later than 1 (one) month since the existence of the criminal element is known. The CPC report as referred to in paragraph (3) shall be the basis of the investigation by the competent investigating authority in accordance with the laws and regulations.

In the case of corruption, a government agency or government official is said to have committed a misappropriation of funds which resulted in the financial loss of the state can be seen by the Report of

Examination Result . The Audit Result Report ofCPC is an audit report of the Supreme Audit Board covering three types, namely:

1. Financial Audit, is an examination of the financial statements of central government and local government. This financial audit is conducted by CPC in order to give an opinion statement about the fairness of the information presented in the government financial statements. 
2. Performance Check is an examination of economic and efficiency aspects, as well as an examination of the effectiveness aspect which is commonly used for management's interest by the government's internal control apparatus.

3. Inspection with Specific Purposes, is an examination conducted with a specific purpose, outside the financial examination and performance checks. Included in the examination of this particular purpose is the examination of other matters relating to finance and investigative investigation. ${ }^{1}$

Review the case experienced by former Makassar Mayor IlhamAriefSirajuddin who has been sentenced to 4 (four) years in prison and a fine of Rp. 100 Million subsidies a month in prison confinement at Jakarta Corruption Court (Corruption). Ilham was also sentenced to pay a refund of Rp 150 million subsidies for one year in prison. Chairman of the public prosecutor's team, RiniTriningsih, read the indictment numbered Dak40/24/09/2015. The act of Ilham, harming the state or regional finances in this case Regional Water Company of Makassar City worth Rp 45.844.159.843,30. ${ }^{2}$ This lawsuit is based on the result of the calculation of State Loss by CPC Number 24 / HP / XIX / 09/2015 dated September 18, 2015.

Another case that was presented was a pretrial case filed by the applicant Vice Chairman of DPRD BanggaiKepulauan District Hi. SulemanHusen in Luwuk District Court. Hi. SulemanHusen was made a suspect and was accused of committing a criminal act of corruption in the use of travel budget of the leadership and members, as well as secretarial staff of DPRD of BanggaiKepulauan Regency. In the verdict of the district court of Luwuk. 05 / Pid.Pra / 2016 / PN.Lwk declare to grant the petition of the petitioner to the whole, stating the petitioned / prosecutor action stipulates the applicant as a suspect who has allegedly committed a corruption crime on the official trip of the officers and members, and secretariat staff of BanggaiKepulauan Regency DPRD in the 2012 / 2013 is invalid, declares the investigation report of the applicant as a suspect dated February 5, 2015, unlawful and null and void with all legal consequences; etc. From the consideration of the judge in deciding the decision to grant the petition of the applicant based on unqualified evidence such as lack of documentary evidence or other documents explaining the results of the CPC audit which determined the existence of state losses in accordance with the mandate of Article 10 paragraph (1) of Law no. 15 of 2006 About CPC.

From two cases that the authors describe above can be appreciated how strong and timely documents CPC examination results contained in the form of LHP. Our law enforcers make the basis of evidence as evidence both evidence of beginning and evidence in the prosecution and trial process.

Our law enforcement officers as if to justify that LHP CPC is a perfect evidence in determining a person who is a criminal actor of corruption and to prove the actual acts of corruption that occur while various questions often appear dibenak us the extent to which the strength of proof of CPC audit results can be accepted as evidence legitimate.

\section{RESEARCH METHODS}

The type of research used is normative juridical legal research conducted based on norms and rules and regulations. In this study the library material is the basic data in the science of research classified as secondary data. Normative Law Research (normative juridical) is a method of legal research conducted by examining library materials or secondary data only. This research was conducted to identify the concepts and principles as well as the strength of evidence of a document of CPC's audit results in cases of corruption.

\section{RESULT AND DISCUSSION}

\section{The Power of Proof of the Audit of CPC as Proof of In Case of Corruption Crime.}

Proof is the central point in court case investigation. This is because through this stage of proof occurs a process, manner and deed proves to show true wrong the defendant against a criminal case in court.The proof is the presentation of legal evidence by the judge who examines a case to provide certainty about the truth of the event presented. In this case the Public Prosecutor shall be obligated to prove the events presented by submitting evidence in advance of the trial to be judged truthful by the Panel of Judges. Then the Public Prosecutor, the Legal Counsel and the Panel of Judges conduct legal review. By the Public Prosecutor, the result of the proof is made in the letter of demand (requisitoir). Then the Legal Counsel responds to the indictment of the Public Prosecutor in a defense plea (pledoi), and will be discussed by the Panel of Judges in the final verdict.

1. Dr. CrisKuntadi, http: //criskuntadi.blogspot.co.id/2008/10/check-cpe top-inaccess hours. 20.00 wita manajemen.html23 / 12/17

2. East Tribune on line Available at http: //n.php? Idu $=28$ \&idsu $=35$ \&idke. Last accessed on March 18, 2016, 8.49 PM WIT 
In the prosecution of the Public Prosecutor, the Legal Counsel and the Panel of Judges presiding over the criminal proceedings at the hearing must take into account the provisions of the law of evidence which govern the manner of proof, burden of proof, various evidence, and the strength of the evidence; etc.

The following will be discussed on the definition of evidence according to experts: MartimanProdjohamidjojo points out that: ${ }^{3}$ The proof contains the purpose and endeavor to declare the truth of an event, so that it is reasonable to the truth of the event.

"DarwanPrinst argues that: ${ }^{4}$

"Proof is the proof that a criminal event has taken place and the defendant is guilty of doing so, so it has to account for it."

M. YahyaHarahap states that: ${ }^{5}$

"Proof is the provisions that contain the rulings and guidelines on the ways in which the law prove the guilt of the defendant. Proof is also a provision that regulates the instruments of evidence justified by law and may be used by the judge to prove the wrongdoing.

"HariSasangka and Lily Rosita conveyed that: ${ }^{6}$

"The Law of Evidence is a part of a criminal procedural law that regulates all kinds of legal evidence, thesystem adopted in the proof, the terms and procedures of the evidence and the authority of the judge to accept, reject and judge a proof.

\section{The Principles of Proof}

The principles of proof include:

a. Things that are generally known do not need to be proven. This principle is contained in Article 184 paragraph (2) of KUHAP which reads:"Things that are generally known do not need to be proven" or called by the term notoirefeiten. Broadly speaking the facts notoir is divided into two groups, namely:

1) Something or events that are known to the public that something or event is already so or should be so. What is meant is, for example, the price of gold is more expensive than silver. And what is meant by the event, for example, on August 17 held the commemoration of Indonesia's independence day.

2) .As a reality or experience is forever and always results in such or is always such a conclusion. For example, wine is included in liquor which in certain doses can cause a person to get drunk.

b. Being a witness is a duty.

The obligation of a person to be a witness is stipulated in the explanation of Article 159 paragraph (2) of KUHAP which states:

"A person who becomes a witness after being summoned to a court of law to give testimony but by denying that obligation he may be subject to a criminal offense under the provisions of applicable law. So is the expert. "

c. One witness is not a witness (unus testis nullus testis)

Article 185 paragraph (2) of KUHAP which reads:

"The description of a witness alone is not sufficient to prove that the defendant is guilty of the deed charged to him".

According to the Criminal Procedure Code, the testimony of one witness not a witness does not apply to prompt examination. This can be inferred from the explanation of Article 184 KUHAP as follows:

"In the event of speedy examination, the judge's conviction is supported by only one legal evidence".

According to M. YahyaHarahap: ${ }^{7}$

"This means one witness, one expert statement, one letter, one clue, or a statement of the defendant accompanied by a judge's conviction is sufficient as evidence to convict the defendant in a speedy case."

The defendant's acknowledgment did not remove the obligation of the public prosecutor to prove the defendant's wrongdoing. This principle is an affirmation of the opposite principle of "reverse proof" that is not recognized by the applicable criminal procedure law in Indonesia.

According to Article 189 paragraph (4) of KUHAP:"The defendant's description is not sufficient to prove that he is guilty of committing the deed charged to him, but must be accompanied by other evidence".

d. The defendant's statement is only binding on himself

3. MartimanProdjohamidjojo. Comment on Criminal Procedure Code: Criminal Procedure Code, Jakarta, 1984, p.11

4. DarwanPrinst. Criminal Procedure Code In Practice, Djambatan, Jakarta, pp. 133

5. M. YahyaHarahap, Discussion on Problems and Implementation of Criminal Procedure Code: Court Judgment, Appeal, Cassation, and Review, Second Edition, SinarGrafika, Jakarta, 2003, p.273.

6. HariSasangka and Lily Rosita, Law of Proof in Criminal Case, Mandarforward Bandung, 2003. Page. 10.

7. M. yahyaHarahap.Op.Cit. Page 267 
This principle is regulated in Article 189 paragraph (3) of the Criminal Procedure Code which reads: "Defendant's description can only be used against himself". This means that what the defendant explained in court should only be accepted and recognized as valid and binding evidence for the defendant himself.

M. YahyaHarahap argues that:

"According to this principle, what a person explains in a court of law as a defendant can only be used as an evidence against himself. If in a case the defendant consists of several persons, each of the defendant's statements is only a binding evidence to himself. Defendant A's information can not be used against defendant $\mathrm{B}$, and vice versa."

The Supreme Audit Board is an agency authorized by law to audit state financial management. In Article 23 E Paragraph (1), it is formulated that to examine the management and responsibility of the state finances shall be established a free and independent Audit Board. ${ }^{8}$ In addition to the Constitution of the Republic of Indonesia 1945 which became the legal basis for the existence of CPC is also regulated in a separate law, namely Law Number 15 Year 2006 About the State Audit Board.

Article 2 paragraph (2) states that CPC shall conduct audit on the management and responsibility of state finances. And Article 3 Audit of state financial management and responsibility carried out by CPC shall cover all elements of state finances as referred to in Article 2 of Law Number 17 Year 2003 regarding State Finances. ${ }^{9}$ In carrying out the state finance audit of CPC on duty CPC has the duty to examine the management of and accountability of state finances conducted by the Central Government, Regional Government, other State Institutions, Bank Indonesia, State-Owned Enterprises, Public Service Bodies, BUMDs and other agencies or bodies managing state finances, referred to in paragraph (1), shall be made in accordance with the law concerning the audit of management and financial responsibility of the state. CPC checks include financial checks, performance checks, and checks for specific purposes. ${ }^{10}$ In case the examination is carried out by a public accountant pursuant to the provisions of the law, a report on the results of the examinationbut must be submitted to CPC and published, In conducting the audit of state financial management and responsibility as referred to in paragraph (1), CPC shall discuss the audit findings with the objects examined in accordance with state auditing standards. Further provisions concerning the procedures for the implementation of the CPC duties as referred to in paragraph (1) shall be governed by CPC rules.

Evidence, in criminal procedure law, is a very essential part, in order to determine the fate of a defendant. The guilty or innocence of a defendant, as indicted in the indictment, is determined on the proofing process. Evidence is an attempt to prove the truth of the contents of the indictment, delivered by the public prosecutor, whose use is to obtain the true truth (material) to the question. Which deeds are deemed proven according to the trial examination. Has it been proven, that the defendant has been guilty. What crime is done. What punishment is droppeSd.

\section{Results of CPC Examination as Investigation and Investigation Material.}

Legal aspect of proof of principle has been started since the investigation stage of criminal case, when the investigator to find and find the suspected event as a crime in order to obtain or not, conducted investigation, at this stage there has been evidence, with the action of investigators to search for evidence, meaning to make the light of a crime and determine or find the suspect. So the concrete verification begins with the investigation and ends in a criminal (vonnis) sentence by the judge in front of the court, both at the district court level, the high court as well as the legal remedies to the Supreme Court. The process of substantiation is indeed more dominant in the trial, in order to find the material truth (material waaheid) of events that occur and give confidence to the judge about the incident so that the judge can give the fairest verdict. ${ }^{11}$

In accordance with the authority given by the law, if in the investigation found the existence of a criminal offense of the Supreme Audit Agency may report it to the competent authority (Article 8 paragraph (3) of Law 15 of 2006, Article 62 paragraph (2) Law 1 year 2004 on state treasury, Article 14 paragraph (1) of Law 15 of 2004 on Audit of Financial Management and State Finance Responsibility). The CPC report is affirmed in Law 15 Year 2006 as the "basis of investigation" authorized in accordance with the laws and regulations (Article 8 paragraph (4).

According to Article 7 paragraph (2) of Law 15 Year 2006 concerning the Supreme Audit Board, namely: "DPR, DPD and DPRD follow up the results of inspection as referred to in paragraph (1) in accordance with the Rules of Procedure of each representative institution". ${ }^{12}$

\footnotetext{
8. Amendment to 4 of the 1945 Constitution of the State of the Republic of Indonesia.

9. Law Number 15 Year 2004 on Audit of Management and Responsibility of State Finances

10. Article 6 paragraph (3) of Law Number 15 Year 2006 concerning the State Audit Board

11. SyaifulBakhri, Legal Proof of Criminal Justice Practice, Total media Jogyakarta 2009.Pages. 26-27

12. Law Number. 15 of 2004 About the Audit of Financial Management and State Financial Responsibility.
} 
For the purposes of such follow up, so Article 8 paragraph (1) and (2) states that the Supreme Audit Board shall submit the results of written examination to the president, governor, regent / mayor in accordance with their authority. Follow-up results of CPC audit are notified in writing by the president, governor, and regent / mayor to CPC. The provision is also affirmed in Law 15 of 2004 on Audit of Financial Management and Financial Responsibility of the state, even stated the following details:

Article 20

1) Officials shall follow up on recommendations in inspection report.

2) Officials shall provide answers or explanations to the CPC regarding the follow-up of the recommendations in the inspection report.

3) The answers or explanations as referred to in paragraph (2) shall be submitted to the Supreme Audit Board no later than 60 (sixty) days after receipt of the report.

4) The CPC shall monitor the implementation of the follow-up to the results of inspection as referred to in paragraph (1).

5) Officials known to not perform the obligations referred to in paragraph (1) may be subject to administrative sanctions in accordance with the provisions of the legislation in the field of personnel.

6) The CPC shall notify the results of follow-up monitoring as referred to in paragraph (4) to the representative institution in the results of the semester examination.

Although in the oversight function of the representative body the people did not follow up on the findings in the CPC Audit Report, the findings of state losses ${ }^{13}$ caused by someone's unlawful acts and negligence during which LHP often became the data and early evidence of law enforcement ininitiating the investigation and prosecution process. LHP CPC is always the first evidence of someone reporting the case to law enforcement.That is, not always with the findings of state losses allegedly due to violations of legislation in LHP CPC, law enforcement follow up or representative agencies follow up according to its supervisory function.

The law enforcers themselves did not follow up on the CPC's findings because of the following penalties: no corruption there, insufficient evidence, not a priority for handling cases by the KPK or the police / prosecutors, and no request for follow-up from the DPR or related community reports. In other words, law enforcers do not talk about the existing state losses based on these findings. Thus, on the one hand law enforcers seek and open the truth to events that alleged corruption many depart from LHP CPC and when it wants to prove the existence or indication of state losses also ask CPC to conduct an investigative audit. On the other hand, these two institutions have different duties and functions and standards, so in the process of law enforcement criminal law enforcement does not always follow up the findings of state losses indicated corruption by CPC.

For the findings of state losses due to violations of law and negligence by governors, regents and mayors as leaders, the function of oversight of representative institutions has an important role in addition to law enforcers, especially the KPK. Because for violation of law and negligence by the head of region, the president mungkinkah provide administrative sanctions to the governor. In the position of a top leader in the area, control may be exercised by other branches of power or by a more independent law enforcement, although Law 17 of 2003 on State Finance expressly states:

"Any state official and civil servant are not treasurers in violation of law or neglect their obligations, directly or indirectly, to the detriment of state finances, to compensate for such losses "as well as in Law No. 15 of 2004 on Audit of State Financial Management and Accountability, namely: Officials who are known not to perform obligations as referred to in paragraph (1) may be subject to sanctions administrative in accordance with the provisions of legislation in the field of personnel ". ${ }^{14}$

When the LHP CPC is reported to the DPR, DPD and DPRD and informed to the president, governor, regent and mayor, the DPR then requests the KPK to follow up, KPK as law enforcement must implement it according to standard of investigation, investigation and prosecution. The same thing when people report to the KPK on the basis of CPC findings. With this condition the KPK should address the case as a report and complaints that can not be ignored.

13. State financial loss Article 1 sub-paragraph 15 of Law Number 15 Year 2006 concerning the State Audit Board includes: "State / Region Loss is lack of money, securities, and goods, which is real and certain in number as a result of unlawful acts either intentionally or negligently" . Law Number 1 Year 2004 on State Treasury The state financial loss based on Article 1 Number 22 of Law Number 1 Year 2004 concerning State Treasury states: "the loss of the country / region is lack of money, securities, and goods, which is real and certain in number due to unlawful acts either intentionally or negligently. "

14. Article 35 Paragraph 1 of Law no. 17 of 2003 on State Finance

DOI: $10.9790 / 0837-2303087483 \quad$ www.iosrjournals.org $78 \mid$ Page


Moreover, Law 15 of 2006 authorizes CPC to monitor the implementation of follow-up examination results conducted by central and local government agencies whose results are notified in writing to the DPR, DPD, DPRD, and the Government. This means that the state losses as a CPCfindingscan not simply be ignored by the central and regional governments.

With the existence of LHP CPC and DPR base requesting to follow up the alleged corruption or not criminal, KPK can conduct investigation by coordinating with CPC in order to prove corruption crime. Based on the findings of state losses in violation of laws and regulations, the KPK may examine witnesses and experts and others. To deepen the facts, legal basis, and value of loss, the KPK may request CPC to conduct an investigative audit. Audit results with a specific purpose may strengthen previous audits or even results differ. The KPK can also prove itself outside of the CPC's findings by inviting experts or requesting material from the inspectorate general or a body that has a function in order to prove the material truth. In the process of investigation is inevitable, the Commission makes light of the facts about the elements of the formulation of the offense investigated namely Article 2 paragraph 1) and Article 3 of the PTPK Law. With these two chapters as a starting point, KPK should have focused on the elements in the formulation of the two offenses as a formal offense.

From the process of serious investigation by law enforcers to reveal all the legal facts will be seen whether there are intentional violations of laws and other regulations whether to enrich themselves or others and to benefit themselves or others. Suppose that there is a violation of the law in accordance with the legal facts to be able to declare a discretion justified or not in the administrative law needs more in-depth discussion. If proven elements of the act of unlawfulness in the formal sense include other core elements in the formulation of offense, it is inevitable to finally deal with the inseparable element of "state loss." Likewise, if there is evidence of the use of authority for any other purpose of the purpose given to such authority.

\section{Results of CPC Examination as a Proof of Judicial Tool.}

The results of CPC's examination in many experiences, often used as the initial evidence in the handling of corruption in Indonesia. Therefore, proof in the process of CPC audit is necessary, so that the proof is completely valid. How important is the proof of corruption and how is the calculation of state losses made by CPC become the basis of the amount of state losses? In addition, the CPC Auditor is very often requested as expert information in various court proceedings that require the competence of state finance expertise. regarding the definition of expert information and the results of auditing of CPC as evidence in the judiciary can be explained that expert information is one of the evidences to obtain material truth. the most important part of the criminal procedure law is the proof of whether or not the defendant has committed the alleged act, because at that moment, human rights are at stake. Therefore, the criminal procedure law aims to search for material truth obtained through means of evidence. In assessing the evidentiary power of existing evidence tools, Indonesia embraces the same system of proof as the Netherlands and other Continental European countries, namely the judges withhis own conviction that assesses the evidence presented.

In the science of criminal law, the theory of proof can be represented in 4 groups as follows:

a. Positive law-based proof theory (positiefwettelijkbewijstheorie) or formal proof theory (formelebewijstheorie), ie proof that is based only on the law. This means that if it has proved an act in accordance with the evidence tools mentioned by the law, then the judge's conviction is not necessary at all.

b. The theory of evidence based on the conviction of the judge is a verification based on the conscience of the judge, so that punishment is possible without being based on the evidence in the law.

c. The theory of evidence based on the judge's conviction of a logical reason (la convictonraisonnee), in which the judge may decide a person guilty based on his belief based on the grounds of proof, with a conclusion based on certain rules of evidence.

d. Negative law proof theory (negatiefwettelijk) ie proof must be based on the law accompanied by the judge's conviction obtained by the evidence.

This theory is adopted KUHAP in Indonesia. The negative representation of the theory of evidence based on the law adopted by Indonesia is contained in Article 183 of the Criminal Procedure Code which reads: "The judge shall not impose a penalty on a person, except if with at least two valid evidences he / she obtains the conviction that a criminal act really occurred and that the defendant was guilty of doing so. "As mentioned in Article 184 of the Criminal Procedure Code, the valid evidence is: a. Description of witness b. Expert description c. Letter d. Directions, and e. Defendant's description The placement of expert information on the second sequence after the witness's statement is a representation of the judgmentor's judgment which views the important function of the expert's statement. It can also be noted as one of the progresses in legal reform, as lawmakers are aware that the role of the expert is crucial in the settlement of criminal cases. The development of science and technology also has an impact on the quality of crime methods, so it must be balanced with quality and evidentiary methods that require knowledge and expertise. Thus, the function of experts in the proof of criminal case is already considered significant along with the times. The main idea of seeking evidence by asking for expert information is to make the light of a criminal offense. 
By relating it to Article 184 paragraph (1) and Article 186 of the Criminal Procedure Code with Article 1 point 28 of the Criminal Procedure Code, the valuable expert information as evidence must meet the following criteria:

a. It should be the information given by someone who has special expertise about something that has to do with the criminal case being examined.

b. Whereas the information given by an expert but lacking the special expertise of a state relating to the criminal case concerned, has no value as valid evidence.

Article 120 of the Criminal Procedure Code also affirms the understanding of expert information in terms of evidence and evidence. If it is related to Article 1 point 28 of the Criminal Procedure Code, expert information may be assessed as evidence which has the evidentiary power to have the following conditions:

a. Expertise which has special expertise in the field in connection with the criminal case being examined. The form of information given in accordance with the special expertise it possesses, in the form of information "according to his knowledge".

b. Expert proofing tools do not have binding or often referred to the strength of free evidence or "vrijbewijskracht". That is, the value of the perfect and decisive power of proof is not attached to it.

The judge is not bound to accept the truth of the expert's statement and is free to judge it. In accordance with the minimum principle of proof set forth in Article 183 of the Criminal Procedure Code, an independent expert statement alone without the support of one of the other evidences is insufficient and insufficient to prove the defendant's error. Therefore, expert information must also be supported by other evidence. the results of financial statements (Audit) as evidence Evidence According to Law No. 15 of 2004 About Audit and Responsibility State Finance Definition of Examination is a process of identifying problems, analysis, and evaluation conducted independently, objectively and professionally based on inspection standards, to assess truth, accuracy, credibility, and reliability of information on the management and accountability of state finances. Accordingly, the broad interpretation of the results of the examination is the result of a financial examination or examiner an audited financial statement of an entity by CPC, where the examination is conducted on documents and evidence supporting disclosures in the financial statements.

From these examinations CPC will issue an examination opinion on the fairness of the financial statements.

From the form of proof, the result of the examination is an evidence that includes evidence of writing or letters. Writing or letters are divided into two, namely: a signed letter containing a right or attachment originally intended for verification (deed) and a letter or note not included in the deed category (referred to as non-deed).

The Deed itself is divided into two (2) namely: a deed made by an authorized official for it by a ruler who records what the interested party (referred to as an authentic deed) and a deed made for the purpose of proof by the parties without the assistance of the official (referred to as deed under hand).

Individual deeds, non-deeds, authentic deeds and deeds under their hands have different evidentiary powers, so have different powers of evidence and have different binding legal forces for courts or judges as the party to examine and base their verdict on the basis of evidence the. There is no single formula for classifying the results of CPC audits, including in which written evidence or letters. One party may regard the result of the examination as an authentic deed on the grounds that the inspection result is a statement requested by the auditee and then provided by the competent authority (CPC), the court may assess the strength of the proof to be valid and convincing, or statements in the results of inspection and the financial statements are accepted as truth, unless proven otherwise. The result of the examination is also classified as a deed under the control on the grounds that there is no involvement of a notary, or other land-making official. The results of the examination may also be classified as non-deed, as the results of the examination only examine the financial statements that contain the recording or documentation of an entity. Essentially a party can interpret and construct an examination result entered in what class depends on the interpretation of the party concerned. It should be noted, however, that the results of the examination itself are based on financial statements and supporting documents or records concerning such events. In conducting the examination, the examiner in addition to basing thedescription of the entity, also based on the documents provided entities. There is always the possibility that financial statements and inspection results do not reflect actual circumstances, as they are not the primary source of law. This means that the financial statements and inspection results are based on documents that are not the main source of law. If the statement or the contents of the financial statements of inspection results are based on documents that are not the main source of law presented as evidence in the proceedings, it is likely that the opposing party will object and can prove otherwise.

In proving something the argument must be accompanied by written evidence which is the main source of law, or the main document. The results of examination of the financial statements may be used as evidence as long as the contents in the audit results of the financial statements are obtained from the main source of law and not contrary to the content of the main legal source. Answering the question of how the court treats 
the examination of the financial statements as evidence in court is how a party interprets the results of the examination and how the entity responds to the interpreter's interpretation. In civil procedure law, if one party does not challenge the proposition of another, is considered to accept the proposition proposed by the opponent. Furthermore, if a party wishing to prove a proposition is required to prove it by means of evidence (can be a report on the results of examination).

\section{Position of CPC Inspection Result as Proof of Case of Corruption Crime.}

According to Arens (2008) define audit evidence is:

"Evidence is any information used by the auditors to be established in the established criteria"

(Audit evidence is any information used by the auditor to determine whether the information being audited has been presented in accordance with existing criteria). ${ }^{15}$ In general, evidence is considered valid if (a) is obtained from an independent source outside the organization; (b) resulting from information systems having strong internal controls; or (c) obtained directly by the auditor, rather than from a secondary source.

Whittington \&Pany (2006) states that in carrying out their assignments, the auditor should gather sufficient and competent evidence. Competent evidence is relevant and valid. ${ }^{16}$ The audit evidence which is a supporter of the investigative audit report can not be used directly for the provision of a criminal act of corruption, since the audit evidence is inseparable from the investigation report. However, the audit evidence in relation to the criminal act of corruption can be changed by the investigator to obtain new evidence and / or additional evidence leading to legal evidence. To obtain a clear picture of the change in each type of audit evidence into legal evidence can be described as follows:

\section{Physical Examination}

In this physical examination, the examiner conducts inspection / examination or calculation of physical assets / assets either project, agency, or business entity. This physical examination is generally performed auditor together with audits. The results of physical testing is poured in the form of a physical examination event signed by both parties namely auditors and auditors. Based on this police investigation report the investigators can actually take advantage of and explore more information from the auditors that allows the discovery of evidence because the Minutes of Physical Examination is reviewed from the level of audit evidence is direct evidence that is proving facts without conclusions or assumptions, shows a fact or matter in question by watching or seeing for yourself. For example: a physical work done by the provider / supplier of goods / services of the work unit / project / business entity is stated in the Official Report of Work Completion has been 100\%, so that 100\% payment has been made At the time the auditor and audited the physical examination completed $100 \%$, then the shortage of physical work is witnessed by both auditors and auditors. From the audit evidence of the Examination Report (BAP) of this Physical, the investigator can change / develop into evidence:

a. Statement of witnesses, if audited:

Hearing, seeing, and experiencing the crime that occurred (Article I point 27 KUHAP).

- Only knowing events or circumstances at the time of physical examination done, but when connected with other witnesses can prove the existence of a particular event or circumstance (Article 185 paragraph (4) KUHAP).

b. Explanation of the defendant, if the audite was involved in a crime that occurred. If the defendant denies the facts or deeds of the accused, the defendant's statement on the audit evidence in the form of a Physical Examination Report may be a statement of the defendant outside the hearing that the judge may assist in finding evidence in the court, provided that the document is supported by a legal evidencing instrument (Article 189 paragraph (2) of the Criminal Procedure Code).

The statements of witnesses and statements of defendants at the hearing in relation to the LHAI containing the Minutes of Physical Examination, can be found evidence evidence, as set forth in Article 188 Criminal Code jo Article 26A of Law Number 20 Year 2001. Thus the evidence of physical testing can be developed by the investigator into evidence of witness testimony, and the statement of the defendant and may be prepared by the APIP auditor to use the judge to find evidence evidence.

2. Confirmation.

Confirmation proof is obtained-by asking questions in order to obtain confirmation from an independent third party. An independent third party is a party outside the auditing management system. The party is involved in an event by auditing, thus by no means off completely. This confirmation evidence is more

15. Muhammad Fuad, Constraints Investigator Transforming Audit Evidence Becoming Legal Proof In Case of Corruption, WidyaiswaraUtama At Center for Education and Training of CPCP Supervision. Page. 4

16. Whittington, O. Ray and Pany, Kurt.Principles of Auditing and Other Assurance Services, 15 / e, 2006 McGraw-Hill Higher Education.quoted in Marwan hadi, VS audit evidence Legal evidence, Ministry of Finance of RI, Board of Education and Training of finance STAN, 2012. 
directed to be changed / developed by the investigator as evidence of witness testimony, if it has or has ever had a legal relationship with auditing activities.

\section{Document Proof (Document)}

The document is a type of audit evidence obtained from test results conducted by the auditor of documents and records that support audit information. Documents or records tested by this auditor are documents or records concerning the conduct of auditing activities. In connection with the evidence according to the criminal law, the document evidence is one of the audit evidence that can meet the criteria of documentary evidence as referred to in Article 187 of the Criminal Procedure Code. However, not all document audit evidence can be self-evident letters, as sometimes the document to be a proof of a letter must be supported with the conformity of other evidence. Thus, documentary evidence can be developed by the investigator into evidence of witness statements, letters, and statements of the accused, and may be prepared by the auditor to become a source / reference for judges to find evidence evidence.

\section{Evidence of Observation (Observation)}

Evidence of this observation audit is the impression that the auditor obtains from the observation scores only or in other words is the allegation of the auditor, so that the allegation can not be accepted as evidence of witness testimony in accordance with Article 185 paragraph (5) KUHAP, which reads:

"Both opinion and invention, derived from the thought only, are not witness statements";

\section{Evidence of Questions and Answers with the Audit (Inquires of the Client)}

As well as evidence of audit observation, this audit evidence is of low reliability because it comes from the auditor's answer, so the information obtained tends to favor auditing interests and is less independent. This audit evidence may be an uncertain statement (hearsay) therefore the auditor needs to obtain further tangible audit evidence by carrying out other audit procedures. Usually the proof of question and answer is set forth in Minutes of Clarification (BAK). Although, according to the auditor, this evidence has a low level of reliability, but in the context of legal evidence, audit evidence with audits can also be developed by the investigator into evidence of testimony of witnesses and statements of the defendant.

\section{Re-implementation (Reperformance)}

Implementation is a type of audit evidence obtained by re-checking a sample of computations and transfers of information performed by auditee during the periods to be audited. Considering that in this evidence there is an "assessment by the auditor" then based on the provisions of Article 185 paragraph (5) of the Criminal Procedure Code can not be changed into witness statements, but the most appropriate is the result of this assessment being questioned in the capacity as an expert giver.

\section{Analytical Procedures}

The analytical procedure is a type of audit evidence obtained through comparison and relationships to determine whether the available data shows reasonableness. This audit evidence usually produces an indication, therefore the auditor needs to prove the truth $\mathrm{n}$ such indication materials. Thus, this type of audit evidence of the Procedure of Analysis has not been a clear and definite evidence as defined in the criminal law that is seeking material truth, it is difficult to be changed / developed into legal evidence.

\section{CONCLUSIONS}

Based on the description of this discussion, the following conclusions can be drawn:

1. The Power of Proof of the Audit of CPC can be made as a valid and perfect evidence to prove the defendant's mistake in the examination of corruption cases.

2. Position of Examination Result of Supreme Audit Board as evidence of letter (document) in case of criminal act of corruption. The content of the results of the financial examination contains opinions, the results of the examination of the performance contains findings, conclusions, and recommendations. And the results of the examination with a specific purpose contain conclusions.

\section{Suggestions}

From the above conclusions the author of this dissertation provides suggestions as follows:

1. Any case of corruption both in the level of investigation and the court shall use the Audit Result Report of CPC as evidence to determine the existence of state losses.

2. Under Law 15 Year 2006 concerning the Supreme Audit Board Article 8 paragraph 4. There should be additional articles / clauses stating that in addition to CPC Report can be used as the basis of investigation, can also be used as evidence. 


\section{BIBLIOGRAPHY}

[1] Ahmad K. and Djanggih H. (2017). Batasan Penerapan Asas Persidangan Terbuka untuk Umum dalam Siaran Persidangan Pidana oleh Media. JurnalIusQuiaIustum, $24 \quad$ (3), 488505.DOI.10.20885/iustum.vol24.iss3.art8. http://journal.uii.ac.id/IUSTUM/article/view/8644/8095.

[2] DarwanPrinst. Criminal Procedure Law In Practice, Djambatan, Jakarta.

[3] HariSasangka and Lily Rosita, Legal Proofs in Criminal Case, MandarMaju Bandung, 2003.

[4] M. YahyaHarahap, Discussion on the Problems and Implementation of the Criminal Code: CourtJudgment, Appeal, Cassation, and Review, Second Edition, SinarGrafika, Jakarta, 2003.

[5] Djanggih, H., \& Ahmad, K. (2017). The Effectiveness of Indonesian National Police Function on Banggai Regency Police Investigation (Investigation Case Study Year 20082016). JurnalDinamikaHukum, 17(2), 152-157. DOI: 10.20884/1.jdh.2017.17.2.722

[6] Djanggih, H., \& Salle, S. (2017). AspekHukumPengadaan Tanah bagiPelaksanaan Pembangunan untukKepentingan Umum. Pandecta: Research Law Journal, 12(2), 165172DOI: http://dx.doi.org/10.152 94/pandecta.v12i2.11677

[7] MartimanProdjohamidjojo. Comment on Criminal Procedure Code: Criminal Procedure Code,Jakarta, 1984.

[8] Muhammad Fuad, Constraints Investigator Transforming Audit Evidence Becoming Legal Proof InCase of Corruption, WidyaiswaraUtamaAt Center for Education and Training of CPCP Supervision.

[9] SyaifulBakhri, Legal Proof of Criminal Justice Practice, Total Media Jogyakarta 2009.

[10] Whittington, O. Ray and Pany, Kurt. Principles of Auditing and Other Assurance Services, 15 / e,2006

[11] McGraw-Hill Higher Education.quoted in Marwan hadi, VS audit evidence Legal evidence,Ministry of Finance of RI, Board of Education and Training of finance STAN, 2012.

[12] Legislation :1945 Constitution of the State of the Republic of Indonesia Changes To. 4

[13] Law no. 17 of 2003. About the state's finances

[14] Law Number 15 Year 2004 on Audit of Management and Responsibility of State Finances.

[15] Law Number 15 Year 2006 concerning the Supreme Audit Board.

[16] Internet:Dr. CrisKuntadi, http: //criskuntadi.blogspot.co.id/2008/10/check-CPC-at- in access hours. 20.00 wita manajemen.html23 / 12/17

[17] East Tribune on line Available at http: //n.php? Idu = 28 \&idsu = 35 \&idke. Last accessed on March 18, 2016, 8.49 PM WIT

IOSR Journal Of Humanities And Social Science (IOSR-JHSS) is UGC approved Journal with S1. No. 5070, Journal no. 49323.

HambaliThalib "Strength Of Proof Of Examination Result Of Financial Auditing BodyIn CaseOf CorruptionCrime" IOSR Journal Of Humanities And Social Science (IOSR-JHSS). vol. 23 no. 03, 2018, pp. 74-83. 